\section{Antibacterial properties of an Indian traditional medicinal plant, Rhynchosia scarabaeoides (L.) DC (Fabaceae)}

\author{
Surekha Challa, ${ }^{1}$ Kiran K. Rajam, ${ }^{1}$ \\ Vishnu V.V. Satyanarayana Kasapu, 1 \\ Suresh Kumar Tanneeru,2 \\ Venkata Siva Satyanarayana \\ Kantamreddi2 \\ 1 GITAM Institute of Science, GITAM \\ University, Visakhapatnam, 2Department \\ of Chemistry, GITAM University, \\ Hyderabad Campus, Andhra Pradesh, \\ India
}

\section{Abstract}

Rhynchosia scarabaeoides (L.) DC plant parts are extensively used by traditional healers in India to treat a variety of bacterial diseases, such as dysentery, diarrohea and skin disorders. This article reports the antibacterial activities of $n$-hexane, ethyl acetate and ethanol extracts belonging to the leaf, stem and root parts of $R$. scarabaeoides against five bacterial strains, Bacillus subtilis, Escherichia coli, Klebseilla pneumonia, Proteus vulgaris and Staphylococcus aureus, using an agar gel diffusion method. The range of inhibition zone (IZ) was found to be $15-24 \mathrm{~mm}$ and the minimum inhibitory activity (MIC) was found to be $1 \mu \mathrm{L} /$ well. The IZ was found to be higher in ethyl acetate extracts while this was moderate in ethanol extracts, and no activity was seen with $n$-hexane extracts or root extracts. The MIC value of leaf ethyl acetate extract was found to be $1 \mu \mathrm{g}$ against bacterial strains $P$. vulgaris and $S$. aureus, whereas $2 \mu \mathrm{g}$ was found against $B$. subtilis, $K$. pneumoniae and $E$. coli. These results support the traditional usage of $R$. scarabaeoides plant parts in the treatment of bacterial infections. Interestingly, this plant was screened for antibacterial activity for the first time and was found to be active. Detailed chemical investigations are, therefore, warranted.

\section{Introduction}

The genus, Rhynchosia belongs to the Fabaceae family, which includes more than 100 species; 22 species are to be found in India.1,2 The species, Rhynchosia scarabaeoides (L.) DC (Atylosia scarabaeoides (L.) Benth.) is found in the tropics of both hemispheres. It is widely available in the forests of Andhra Pradesh (Eastern Ghats of India) and in the native language, Telugu, is commonly called Gadi-chikkudu-kaya. It is of small to medium size and is found as twining or as erect herbs or shrubs. Its stem is very slender with a slight pubescence at the lower part. Leaves are sub-coriaceous or membranous, $0.75-2.5 \mathrm{~cm}$ wide, and are conspicuously gland-dotted with yellow flowers in shortpeduncled racemes. Its pods are $1.25-1.5 \mathrm{~cm}$ long, and are glabrescent and mostly 2 -seeded. The plant is characterized by its two ovules with a compressed central funiculus and often falcate pod, and by papilionaceous flowers which are beardless. 1,2

All the parts of the $R$. scarabaeoides plant have been known for their medicinal uses since ancient times and are routinely used in Indian traditional medicine for the treatment of a variety of diseases. ${ }^{3-6}$ Its leaf decoction is used for dysentery and, in particular, it is given with honey to women after childbirth. ${ }^{7}$ The whole plant material is pounded in coconut oil and is applied on the scalp to control hair loss. It is also used to cure diarrohea in cattle. ${ }^{7}$

The present study is aimed at investigating the antibacterial activity of $R$. scarabaeoides in order to validate its traditional use. All parts of $R$. scarabaeoides were, therefore, tested for antibacterial activity in vitro.

\section{Materials and Methods}

\section{Plant material}

The plant materials of Rhynchosia scarabaeoides were collected from Rajahmundry $\left(16^{\circ} 59^{\prime} \mathrm{N}, 81^{\circ} 47^{\prime} \mathrm{E}\right.$, Andhra Pradesh, India) in June 2010. The identity of this plant was confirmed by taxonomist, Prof. M Venkataratnam, (Department of Botany, Andhra University, Visakhapatnam, A.P., India) and the voucher specimens (100601) were deposited at the Department of Chemistry, GITAM University, India.

\section{Soxhelt extraction}

The leaves, stems and roots were collected and air dried. The dried and pulverized plant materials $(10 \mathrm{gm})$ were packed in a Soxhlet and later extracted successively with hot hexane, ethyl acetate and ethanol for $12 \mathrm{~h}$ each. The resultant extracts were concentrated under vacuum to give hexane, ethyl acetate and ethanol concentrates.

\section{Sample preparation}

The crude extracts or control-drug stock solutions $(1 \mathrm{mg} / \mathrm{mL})$ were prepared by adding $50 \mu \mathrm{L}$ of dimethyl sulphoxide (DMSO) to $1 \mathrm{mg}$ of extract / drugs and made up to $1 \mathrm{~mL}$ with
Correspondence: Dr. Venkata Siva Satyanarayana Kantamreddi, Assistant Professor, Department of Chemistry, GITAM University, Hyderabad - 502 329 , Andhra Pradesh, India.

Tel. $+91.8455 .220 .556 / 57$ - Fax: +91.8455 .220 .046$ E-mail: kantamreddi@yahoo.com

(or)kantamreddi@gmail.com

Vishnu V.V.S. Kasapu, Assistant Professor, Department of Chemistry, GIS, GITAM University, Visakhapatnam - 530 045, Andhra Pradesh, India.

Tel. + 91.891.2840466 - Fax: + 91.891.2790032.

E-mail: kvvvorg@yahoo.co.in

Key words: Indian System of Medicine, Rhynchosia scarabaeoides, Fabaceae, antibacterial activity, agar well diffusion, minimum inhibitory concentration, minimum inhibitory activity.

Acknowledgements: authors express their gratitude to the President, Vice Chancellor, Pro-Vice Chancellor, Registrar, GITAM University for facilitating necessary congenial environment to carry out research work and encouragement in their endeavors. Also, the authors thank the Department of Biochemistry and the Department of Chemistry for extending their constant support.

Contributions: SC, VVSK, VSSK, study investigations; KKR, biological investigations; SKT, survey of ethnobotanical information, collection of plant parts, extraction and other phytochemical investigations.

Conflict of Interest: the authors have declared that there is no conflict of interest.

Received for publication: 17 August 2011.

Revision received: 28 0ctober 2011.

Accepted for publication: 10 November 2011

This work is licensed under a Creative Commons Attribution NonCommercial 3.0 License (CC BYNC 3.0).

(C) Copyright S. Challa et al., 2011

Licensee PAGEPress, Italy

Alternative Medicine Studies 2011; 1:e17

doi:10.4081/ams.2011.e17

double distilled water. These were used for antimicrobial tests. Later these solutions were gradually diluted as required.

\section{Cultivation of microorganism}

The five bacterial strains used in this study are: Bacillus subtilis (NCIM 2063), Escherichia coli (NCIM 2066), Klebseilla pneumonia (NCIM 2957), Proteus vulgaris (NCIM 2027) and Staphylococcus aureus (NCIM 3021). All were obtained from the National Chemical Laboratory (NCL), Pune, India. The bacterial cultures were maintained on Luria Bertani Agar (LB) at $4^{\circ} \mathrm{C}$ temperature according to the methods of Sambrook et al., 1999.8 The subculture was carried out every 21 days using fresh medium. 
Table 1. Antibacterial activities of leaf and stem extracts of Rhynchosia scarabaeoides.

\begin{tabular}{|c|c|c|c|c|c|c|c|}
\hline \multirow{3}{*}{ Micro-organism } & \multirow{3}{*}{ Control* } & \multicolumn{4}{|c|}{ Zone of growth inhibition in mm } & \multirow{2}{*}{\multicolumn{2}{|c|}{ Ethanol Ext. }} \\
\hline & & \multicolumn{2}{|c|}{ Hexane Ext. } & \multicolumn{2}{|c|}{ EtOAc Ext. } & & \\
\hline & & Leaf* & Stem* & Leaf* & Stem* & Leaf* & Stem* \\
\hline Bacillus subtilis & $15 \pm 1$ & ND & ND & $16 \pm 1$ & $14 \pm 2$ & $16 \pm 1$ & $15 \pm 1$ \\
\hline Escherichia coli & $14 \pm 1$ & ND & ND & $16 \pm 1$ & $15 \pm 2$ & $15 \pm 1$ & $13 \pm 1$ \\
\hline Klebseilla pneumonia & $11 \pm 1$ & ND & ND & $16 \pm 1$ & $14 \pm 2$ & $15 \pm 1$ & $12 \pm 1$ \\
\hline Proteus vulgaris & $15 \pm 1$ & ND & ND & $22 \pm 2$ & $18 \pm 1$ & $18 \pm 2$ & $15 \pm 1$ \\
\hline Staphylococcus aureus & $15 \pm 1$ & ND & ND & $24 \pm 1$ & $18 \pm 2$ & $24 \pm 1$ & $15 \pm 1$ \\
\hline
\end{tabular}

ND, not detected; Ext, extract; EtOAc, ethyl acetate; *10 $\mu \mathrm{L} /$ well; Control: ampicillin.

\section{Antimicrobial assay}

A pour plate method was adopted for antibacterial screening. 8,9 Inoculum of test organisms was prepared by growing pure isolate in nutrient broth at $37^{\circ} \mathrm{C}$ overnight. These cultures were sub-cultured in fresh nutrient broth and were incubated at $37^{\circ} \mathrm{C}$ for $3 \mathrm{~h}$ to obtain log phase culture. The agar plates were prepared by a pour plate method using $20 \mathrm{~mL}$ nutrient agar medium per bacteria. The molten sterile medium was cooled to $45^{\circ} \mathrm{C}$ and was mixed thoroughly with $10 \mu \mathrm{L}$ of growth culture of the test organism under study $\left(1 \times 10^{8}\right.$ cells). It was then poured into sterile petriplates and allowed to solidify. Wells (6 $\mathrm{mm}$ ) were made with sterile gel puncture and $10 \mu \mathrm{L}$ of plant extract was aseptically added to each well. A control drug, ampicillin (10 $\mu \mathrm{g} / \mu \mathrm{L}$ ), was used as standard positive antibacterial agent along with plant extract samples. These nutrient agar plates were incubated at $37^{\circ} \mathrm{C}$ for $24 \mathrm{~h}$. The diameter of zone inhibition was measured in mm using a Himedia zone reader. The minimum inhibitor concentration (MIC) was determined by an agar diffusion method. The extracts were incorporated into nutrient agar at concentrations from $1 \mu \mathrm{L}$ to 10 $\mu \mathrm{L}$. A control plate without the extract was also set up. The lowest concentration of extract that inhibited the growth of microorganisms was considered the MIC.

\section{Results and Discussion}

The antibacterial activities of Rhynchosia scarabaeoides extracts were tested against five bacterial strains: Bacillus subtilis, Escherichia coli, Klebseilla pneumonia, Proteus vulgaris and Staphylococcus aureus (Table 1). Data were expressed as the mean \pm standard deviation of the inhibition zone (IZ) of three independent experiments on different days. The IZ (10 $\mu \mathrm{L} /$ well) values of extracts ranged from 12 $24 \mathrm{~mm}$ whereas that of the control drug, ampicillin, ranged from $11-15 \mathrm{~mm}$. It was found that the hexane extracts of leaf and stem parts of $R$. scarabaeoides did not demonstrate any activity against the microorganisms tested, whereas ethyl acetate and ethanol extracts demonstrat- ed different levels of antibacterial activity against different bacteria. No activity was seen with root extracts.

The ethyl acetate extracts of $R$. scarabaeoides demonstrated a broad spectrum of antibacterial activity ranging from gram positive to gram negative bacteria. Interestingly, leaf ethyl acetate extracts were found to demonstrate significant activity against all tested microorganisms, with an IZ ranging from 15-24 mm. MIC values were $1 \mu \mathrm{g}$ against $P$. vulgaris and $S$. aureus whereas these were $2 \mu \mathrm{g}$ against $B$. subtilis, $K$. pneumoniae and $E$. coli (Table 2). Ethanol extracts also demonstrated antibacterial activity but with moderate inhibitory activity. Also, it was found that $R$. scarabaeoides plant extracts showed higher activity against two bacterial strains, $S$. aureus and $P$. vulgaris, among the screened bacteria. Based on these results, it is evident that the selected plant extracts demonstrated potential antibacterial activities. This supports the use of the plant as an antibacterial agent as part of the Indian system of medicine. ${ }^{7}$

An intensive literature search found that similar antibacterial activities were reported in some previous studies of other species of the genus, Rhynchosia viz. $R$. beddomei and $R$. suaveolens. ${ }^{10,11}$ It was also seen that a few Rhynchosia species had been investigated previously for phytochemicals ${ }^{12-14}$ but no phytochemical studies have so far been reported on $R$. scarabaeoides, in spite of general knowledge of its traditional use. Chemotaxonomic studies indicate that Rhynchosia species normally contain flavonoids and a phenolic type of constituents. For example, gallic acid and its analogs were reported from species such as $R$. volubilis and $R$. minima, isovitexin (flavonoid), and 8 - $C$-prenylquercetin 7,4'-dimethyl ether (flavanol) were reported from the leaves of $R$. cyanosperma along with gallic acid derivatives. ${ }^{15-17}$ These compounds are biologically important and proven to be active in a considerable number of pharmacological studies. ${ }^{16-19}$ For example, antibacterial biphenyl constituents 4(3-methyl-but-2-enyl)-5-methoxy- [1,1' biphenyl]-3-ol and 2-carboxy-4-(3-methyl-but-2enyl)-5-methoxy- [1,1'-biphenyl]-3-ol were reported from $R$. suaveolens. 11 Therefore, it would be worth while carrying out a phytochem-
Table 2. Minimum inhibitory activity values of leaf ethyl acetate extracts.

\begin{tabular}{lc} 
Micro-0rganism & MIC (ug/well) \\
Bacillus subtilis & 2 \\
Escherichia coli & 2 \\
\hline Klebseilla pneumonia & 2 \\
Proteus vulgaris & 1 \\
\hline Staphylococcus aureus & 1 \\
\hline
\end{tabular}

ical investigation of $R$. scarabaeoides in order to isolate the active constituents responsible for the antibacterial activity found in the present study.

\section{Conclusions}

Our findings support the traditional usage of Rhynchosia scarabaeoides plant parts in the treatment of bacterial infections because of their significant antibacterial activity. These plant parts merit further investigation.

\section{References}

1. Allen ON, Allen EK. The Leguminosae. A source book of characteristics, uses and nodulation. The University of Wisconsin Press, Madison, Wisconsin, USA, 1981.

2. Pullaiah T. Flora of Guntur district, Andhra Pradesh. Regency publications, New Delhi, 2000.

3. Janardhanan KP. An enumeration of the medicinal plants of Khed taluka (Maharashtra State). Bull Bot Surv India 1963;5: 363-74.

4. Jain SK, De JN. Observation on ethnobotany of Purulia West Bengal. Bull Bot Surv India 1966;8:237-51.

5. Jain SK. Ethnobotanical research unfolds new vistas of traditional medicine. In: Glimpses of Indian Ethnobotany. SK Jain (ed.) Oxford and IBH Publishing Co., New Delhi, India, 1981, pp.13-36.

6. Dr. Duke's Phytochemical and Ethno- 
botanical Databases. Available from: $<$ http://www.ars-grin.gov/duke/ethnobot. html $>$ [02/25/2011]

7. Jain SK, Defilipps RA. Medicinal Plants of India. Vol. 1. Reference Publications Inc., Michigan, USA, 1991, pp.319.

8. Sambrook J, Fritsch EF, Maniatis T. Molecular Cloning: A laboratory manual. 2nd edition (1989-1999), Cold Spring Harbour Laborataory Press, New York, 1999.

9. Prescott LM, Harley JP, Klein DA. Microbiology. 6th edition, Mc Graw-Hill International Ed., 2005.

10. Bakshu LMd, Raju RRV. Antimicrobial activity of Rhynchosia beddomei. Fitoterapia 2001;72:579-82.

11. Khan KA, Shoeb A. Two antibacterial biphenyls from Rhynchosia suaveolens
Phytochemistry 1984;23:765-6.

12. PubMed: PubMed Central - National Center for Biotechnology Information, National Library of Medicine. Bethesda MD 20894 [02/25/2011].

13. SFS: SciFinder Scholar Online Chemical Abstract Database. American Chemical Society.

14. WoS: Web of Science Online Chemical Abstract Database. Thomson Scientfic, UK.

15. Dama A, Pasupulati R, Otto S, et al. Rhynchospermin, a prenylated flavanol from Rhynchosia cyanosperma. Phytochemistry 1981;20:2058-9.

16. Kinjo J, Nagao S, Tanaka T, et al. Antiproliferative constituents in the plant 8. Seeds of Rhynchosia volubilis. Biol Pharm Bull 2001;24:1443-5.
17. Morris JB. Rhynchosia minima (l.) dc. regeneration, characterization and potential uses for natural products and flavonoids. Plant Genetic Resources Newsletter 2008;153:15-9.

18. Hsieh CL, Yen GC, Chen BY. Antioxidant activities of phenolic acids on ultraviolet radiation-induced erythrocyte and lowdensity lipoprotein oxidation. J Agric Food Chem 2005;53:6151-5.

19. Huang ST, Chen CR, Chieng KT, et al. Inhibitory effects of a rice hull constituent on tumor necrosis factor $\{$ alpha\}, prostaglandin EZ, and cyclooxygenase-2 production in lipopolysaccharideactivated mouse macrophages. Ann NY Acad Sci 2005;1042:387-95. 